\title{
GROWTH OF BANANA PASSIONFRUIT SEEDLINGS (Passiflora tripartita var. mollissima (Kunth) L. H. Bailey) UNDER SALINE STRESS
}

\section{CRECIMIENTO DE PLÁNTULAS DE CURUBA (Passiflora tripartita var. mollissima (Kunth) L. H. Bailey) BAJO ESTRÉS SALINO}

\author{
Fánor Casierra-Posada ${ }^{1}$, Jaime E. Peña-Olmos ${ }^{1}$, Edwin Tejedor ${ }^{2}$
}

${ }^{1}$ Pedagogical and Technological University of Colombia. Faculty of Agricultural Sciences. Plant Ecophysiology Research Group. Avenida Central del Norte, Tunja / Colombia. ${ }^{2}$ Sena Regional Casanare. Corresponding author: fanor.casierra@uptc.edu.co

Rev. U.D.C.A Act. E Div. Cient. 14(1): 31 - 38, 2011

\section{SUMMARY}

High salinity in the root zone affects the growth of many plant species. Soil salinity can lead to reduced emergence and low growth of seedlings. The objective of this study was to evaluate the growth of banana passion fruit (P. tripartita var. mollissima (Kunth) L. H. Bailey) seedlings under saline stress. The salinity effect on growth and dry matter (DM) production of banana passionfruit seedlings was evaluated under greenhouse conditions at Tunja / Colombia. Plantlets were grown in plastic bags filled with soil and $0 ; 20 ; 40$ and $80 \mathrm{mM} \mathrm{NaCl}$ were added to the soil, which induced the following different electrical conductivity levels: 0.70; 2.38; 3.47 and $5.49 \mathrm{dS} \mathrm{m}^{-1}$ respectively. Salt was added gradually to the soil, up to the mentioned concentration. Results indicate significant differences among treatments. Plants of the control treatment without salt had higher number of leaves, total stem + shoot length, specific leaf weight, leaf area and DM in relation to salt treated plants. Leaf area and DM production were drastically reduced by salinity, especially by $80 \mathrm{mM} \mathrm{NaCl}$. The DM partitioning was also affected by salinity, reducing dry matter accumulation in leaves and increasing the DM in petioles + stems + shoots and roots. The findings from the study indicate that banana passionfruit seedlings are moderately sensitive to salt stress.

Key words: Salinity, dry matter, leaf area

\section{RESUMEN}

Las altas concentraciones de sales en la zona cercana a la raíz afectan el crecimiento de muchas especies de plantas. La salinidad en el suelo conduce a la reducción de la emergencia de plántulas y además ocasiona un crecimiento pobre de las mismas. El efecto de la salinidad sobre el crecimiento y producción de materia seca (MS) en plántulas de curuba fue evaluado bajo condiciones de invernadero en Tunja / Colombia. Las plántulas crecieron en bolsas plásticas con suelo en el que se adicionó $\mathrm{NaCl}$ en diferentes concentraciones; $0 ; 20 ; 40$ y $80 \mathrm{mM}$, las cuales indujeron diferentes niveles de conductividad eléctrica: 0,$70 ; 2,38 ; 3,47$ y 5,49 dS $\mathrm{m}^{-1}$ respectivamente. La aplicación de sal al suelo, se realizó de forma gradual hasta llegar a la concentración indicada en cada tratamiento. Los resultados mostraron diferencias significativas entre tratamientos. Las plantas del tratamiento control tuvieron un mayor número de hojas, longitud total de tallos y ramas, peso específico de las hojas, área foliar y MS con relación a las plantas tratadas con sal. El área foliar y la producción de MS se vio fuertemente reducida por la salinidad, especialmente en el tratamiento con $80 \mathrm{mM}$ de $\mathrm{NaCl}$. La distribución de MS también se vio afectada por la salinidad, de tal forma que se redujo acumulación de MS en las hojas e incrementó en los tallos, las ramas y las raíces. Los resultados obtenidos indican que las plántulas de curuba son moderadamente sensibles al estrés salino.

Palabras clave: Salinidad, materia seca, área foliar. 


\section{INTRODUCTION}

In 2009, 1.323ha of banana passionfruit were cultivated in Colombia and the department of Boyacá participated with $52.6 \%$ of the total area in the country (Agronet, 2010). In the Boyacá region, fruit cultivation under non-irrigated conditions has increased considerably, mainly due to the lack of economic resources of farmers for the installation of irrigation systems. This production system causes solute concentration in soil mainly during the dry season, triggering osmotic stress to plants. Modern agriculture management practices also worsen the extent of salinity by remobilizing salts from deep soil layers, therefore, salinity also occur in non-irrigated environments. The soil salinity problem can be reduced through two approaches. One is to make a technology available to users aimed to reclaiming these soils, while the other is based on biological exploitation of such soils through cultivation of salt tolerant plant species (Guasmi et al. 2007).

Many crop species are very sensitive to soil salinity and are known as glycophytes, whereas salt-tolerant plants are known as halophytes. In general, glycophytes cannot grow at $100 \mathrm{mM} \mathrm{NaCl}$, whereas halophytes can grow at salinities over $250 \mathrm{mM} \mathrm{NaCl}$ (Hu \& Schmidhalter, 2005). Salinity-sensitive plants restrict the uptake of salt and strive to maintain an osmotic equilibrium by the synthesis of compatible solutes such as prolines, glycine betaine and sugars. Salinity-tolerant plants have the capacity to sequester and accumulate salt into the cell vacuoles, thus preventing the buildup of salt in the cytosol and maintaining a high cytosolic $\mathrm{K}^{+} / \mathrm{Na}^{+}$ratio in their cells. Because of the competition of $\mathrm{Na}^{+}$and $\mathrm{Cl}^{-}$with other nutrients such as $\mathrm{K}^{+}, \mathrm{Ca}^{2+}$, and $\mathrm{NO}_{3}^{-}$, which reduce plant growth by affecting the availability, transport, and partitioning of nutrients, high salinity stress causes nutrient imbalances (Hameed et al. 2010).

Some plants present a moderate tolerance to salinity per sodium chloride, like naranjilla (Solanum quitoense), that accumulates chloride and sodium ions in tissues, a condition that permits a classification of plant resistance to moderate salinity (Casierra-Posada et al. 2000). However, genotypic differences in salt tolerance between different species or plant varieties, for growth parameters in plants were found (CasierraPosada E García, 2005; Casierra-Posada et al. 2006). On the other hand, fruits are also severely affected by salinity. While salt stress also increases the percentage of protein, fiber, fat, total soluble solids and carbohydrates in fruits of $\mathrm{NaCl}$-treated plants, water content is reduced by salt excess (CasierraPosada E García, 2006; Casierra-Posada et al. 2009).

There is lack of information on the response of banana passionfruit plants to salinity; however, some studies were carried out using yellow passion fruit, Passiflora edulis, which may be useful to understand the behavior of banana passionfruit plants exposed to salt stress, since both species belong to the same genus. $\mathrm{NaCl}$-salinity delayed the germination process in $P$. edulis, but relative reduction was observed only above ECw $4.43 \mathrm{dS} \mathrm{m}^{-1}$ (Soares et al. 2002; Fischer et al. 2009). These authors found that seedling vigor and growth decreased with increased salinity, however, water at $4 \mathrm{dS} \mathrm{m}^{-1}$ resulted in $85 \%$ of vigor and seedlings with more than $50 \%$ growth in comparison to $1.0 \mathrm{dS} \mathrm{m}^{-1}$ (lowest salinity treatment). Based on soil salinity the passion fruit may be considered as moderately tolerant to salinity during the initial phase.

Unlike previous authors, Nyagah $\varepsilon$ Musyimi (2009) categorized passion fruits seeds as very sensitive to salt stress. Their results showed that sodium chloride solution treatment reduced percentage germination of passion fruit seeds, radicle and plumule growth. Thus, the higher salinity reduces the absorption of water and nutrients and carbon accumulation into yellow passion fruit seedlings. This could be explained since with salinity stress the stomata of the seedlings of yellow passion fruit closes in order to minimize the water loss and in this way result in lower production of leaf number, affecting significantly the production of dry matter. It can be inferred that the seedlings of yellow passion fruit begin to experience differences from a high level of salinity (Soares et al. 2002).

Meza et al. (2007) share the opinion of Nyagah $\varepsilon$ Musyimi (2009) in relation to the high sensitivity of $P$. edulis plants on the basis that the germination percentage of passion fruit was affected negatively and significantly with the increment of the saline concentrations. At emergency beginning, plantlets were not affected, while the percentage of total emergency showed significant differences, with trend to diminish when total salt concentration increases. The highest emergency percentage was $79 \%$ with the lowest concentration $(0.75 \mathrm{dS}$ $\mathrm{m}^{-1}$ ) and the less, $48.6 \%$ was $6.5 \mathrm{dS} \mathrm{m}^{-1}$, the most saline.

In the passion fruit crops, salinity responses have been studied in a very limited way; tolerance level to salinity in the growing stages and plant development of banana passionfruit (P. tripartita var. mollissima) is unknown. Because of the lack of information about salinity limit indicated for this species, the objective of this study was to evaluate the growth of seedlings of passion fruit ( $P$. tripartita var. mollissima) under saline stress.

\section{MATERIALS AND METHODS}

Plant growth conditions: The study was conducted in a greenhouse at the Pedagogical and Technological University 
of Colombia (UPTC), Tunja / Colombia $\left(5^{\circ} 33^{\prime} 16,25^{\prime \prime} \mathrm{N}\right.$; $\left.73^{\circ} 21^{\prime} 9,14^{\prime \prime O}\right)$ at 2790 m.a.s.l. Passiflora tripartita var. mollissima seeds were sown in a mixture 1:1 of soil and peat. Average growth conditions inside the greenhouse were: photosynthesis photon flux $782.2 \mu \mathrm{mol} \mathrm{m}^{-2} \mathrm{~s}^{-1}, 15.8^{\circ} \mathrm{C}$ temperature and $72 \%$ relative humidity. Four weeks after germination, single seedlings were transplanted to plastic bags filled with soil. Four concentration of salt $(0 ; 20 ; 40$ and $80 \mathrm{mM} \mathrm{NaCl})$ were tested which induced different electrical conductivity (EC) levels $\left(0.70 ; 2.38 ; 3.47\right.$ and $5.49 \mathrm{dS} \mathrm{m}^{-1}$, respectively). The soil in the bags was slowly salinized four weeks after planting until the calculated $\mathrm{NaCl}$ concentration was reached.

Growth measurements: Plants were harvested twelve weeks after transplanting. Then they were dried to determine total dry weight and dry weight of each plant organ (roots, petioles + stem + shoots and leaves), by drying in an oven at $70^{\circ} \mathrm{C}$ for $48 \mathrm{~h}$. The specific leaf weight $\left(\mathrm{mg} \mathrm{cm}^{-2}\right)$ was obtained as a ratio between the total dry weight of leaves and leaf area of the same plant. The leaf area was measured using an analyzer LI-3000-A (LI-COR, Lincoln, USA).

Statistical analysis: All factors where evaluated in a completely randomized design with a factorial arrangement for four treatments. Treatments were: $0 ; 20 ; 40$ and $80 \mathrm{mM} \mathrm{NaCl}$. For measuring of growth parameters, 10 seedlings were taken. Each seedling was taken as a repetition. All data obtained were subjected to analysis of variance (ANOVA) using SPSS 17.0.0, taking $\mathrm{p}<0,05$ as significant, followed by a post hoc Tukey test.

\section{RESULTS AND DISCUSSION}

For the number of leaves per plant, the total stem and shoots length and the specific leaf weight, significant difference $(p<0.01)$ was found regarding exposure of plants to different salinity levels (Table 1). For these three parameters, it was noted that, despite salinity effects the growth, this is not so severe at a level of $40 \mathrm{mM} \mathrm{NaCl}$, while the concentration of $80 \mathrm{mM}$ drastically reduced growth in values of 86.80 and $41.64 \%$ in relation to control plants, for the number of leaves per plant and total stem and shoots length, respectively, as the specific leaf weight increased in a $88.34 \%$.

In this study, salinity reduced the number of leaves per plant. In fact, in several species such as mangrove, an increase in soil salinity decreases the number of leaves per plant (Clough, 1984; Ball \& Pidsley, 1995). Leaf production and leaf death rates, as well as leaf life span have important physiological consequences for the whole plant, since they determine the total leaf surface area per plant and the rate of leaf turnover, linked to the carbon and nutrient economy of the plant (Ackerly $\varepsilon$ Bazzaz, 1995; Casper et al. 2001). Clough (1984) found that an increase in salinity in seawater from 25 to $50 \%$ caused an increase of up to five times of the leaf mortality over a twelve months period in other mangrove species. Thus, the capacity of the plant to increase the leaf area, probably depends on both its capacity to avoid the increase in ion concentration in leaf tissues and on the maintenance of higher rates of leaf production than of leaf death (Munns \& Termaat, 1986). Similarly, when salinity reaches maximal levels during the dry season, a progressive increase in senescence of older leaves occurs in combination with a decrease in leaf initiation and, under these conditions, a fluctuation in salinity may contribute to the survival of the species (Ball \& Pidsley, 1995).

In the current study, in agreement with previous studies, salinity reduced plant height. In tomato, all growth parameters, such as plant height, leaf area, total chlorophyll and $\mathrm{K}^{+}$contents, fresh weight of areal parts and percentage of dry weight of areal parts, as well as yield and some yield quality parameters, responded negatively to an increase in the salinity level (Tantawy et al. 2009). Height of lemon balm herb plant was affected significantly by water salinity (Ozturk et al. 2004), which is in agreement with Sari \& Ceylan (2002),

Table 1. Parameters values of growth evaluated in seedlings of banana passionfruit (Passiflora tripartita var. mollissima (Kunth) L. H. Bailey) exposed to saline stress.

\begin{tabular}{|c|c|c|c|}
\hline $\mathrm{NaCl}$ & Number of leaves & $\begin{array}{c}\text { Total stem + Shoots } \\
\text { length }\end{array}$ & $\begin{array}{l}\text { Specific leaf } \\
\text { weight }\end{array}$ \\
\hline$(\mathrm{mM})$ & & $(\mathrm{cm})$ & $\left(\mathrm{mg} \mathrm{cm}^{-2}\right)$ \\
\hline 0 & 39.80 & 613.50 & 2.66 \\
\hline 20 & 33.25 & 590.62 & 2.70 \\
\hline 40 & 26.50 & 555.33 & 2.84 \\
\hline 80 & 5.25 & 358.00 & 5.01 \\
\hline
\end{tabular}


who obtained plant height of $41.61-55.79 \mathrm{~cm}$ in Aegean conditions. Also fresh yield, dry yield, number of shoots, root length, root dry weight and evapotranspiration were affected significantly by salt stress in lemon balm plants.

While decreasing specific leaf weight in Furcraea spp. due to salt stress was reported by Casierra-Posada et al. (2006), Casierra-Posada E García (2005) found an increase of this variable in Fragaria sp varieties. Specific leaf weight of Spartina alterniflora increased too in response to both high salinity and high illumination. Many plants show an increase in leaf thickness, mainly in mesophyll cell layers, in response to salinity (Poljakoff-Mayber, 1975; Wignarajah et al. 1975). Longstreth \& Strain (1977) also observed that differences in specific leaf weight at high illumination were the result of differences in leaf thickness. Likewise, as found in these researches, in the current work, the specific leaf weight increased with increasing salinity level, as a mechanism of osmoregulation by plant to tolerate this adverse situation.

As found in the current study regarding the effect of salinity on plant growth, some authors, such as Munns (2002), pointed out that salinity inhibition of plant growth is also the result of osmotic and ionic effects and the different plant species have developed different mechanisms to cope with these effects. The osmotic adjustment, i. e., reduction of cellular osmotic potential by net solute accumulation, has been considered an important mechanism for plant tolerate saline stress. This reduction in osmotic potential in salt stressed plants can be a result of inorganic ion $\left(\mathrm{Na}^{+}, \mathrm{Cl}^{-}\right.$, and $\left.\mathrm{K}^{+}\right)$and compatible organic solute (soluble carbohydrates, amino acids, proline, betaines) accumulations (Hasegawa et al. 2000; CasierraPosada et al. 2009). The osmotic adjustment in both roots and leaves contribute to the maintenance of water uptake and cell turgor, allowing physiological processes, such as stomatal opening, photosynthesis and cell expansion (Serraj E Sinclair, 2002). In addition to their role in cell water relations, organic solute accumulation may also help towards the maintenance of ionic homeostasis and of the $\mathrm{C} / \mathrm{N}$ ratio, removal of free radicals, and stabilization of macromolecules and organelles, such as proteins, protein complexes and membranes (Bohnert \& Shen, 1999; Bray et al. 2000). Moreover, these solutes may also help the control of $\mathrm{pH}$ in the cytosol and detoxification of excess $\mathrm{NH}_{4}^{+}$ (Gilbert et al. 1998). Thus, solute accumulation, essential for osmoregulation, increases the specific leaf weight to the extent that salinity increases.

Dry weight of whole plant, as presented in figure 1 , showed a significant reduction as the salinity level increased. Especially, there was a great reduction in $\mathrm{DM}$ at $80 \mathrm{mM} \mathrm{NaCl}$, which reached $66.97 \%$ in relation to control without salt adding.

Consistent with the reports mentioned above and the findings in this research, it can be noted that salinity causes physiological and biochemical changes in plants. In plants, these changes appear to depend on the effects of ions and solutes in the root zone, on water activity in the cell and

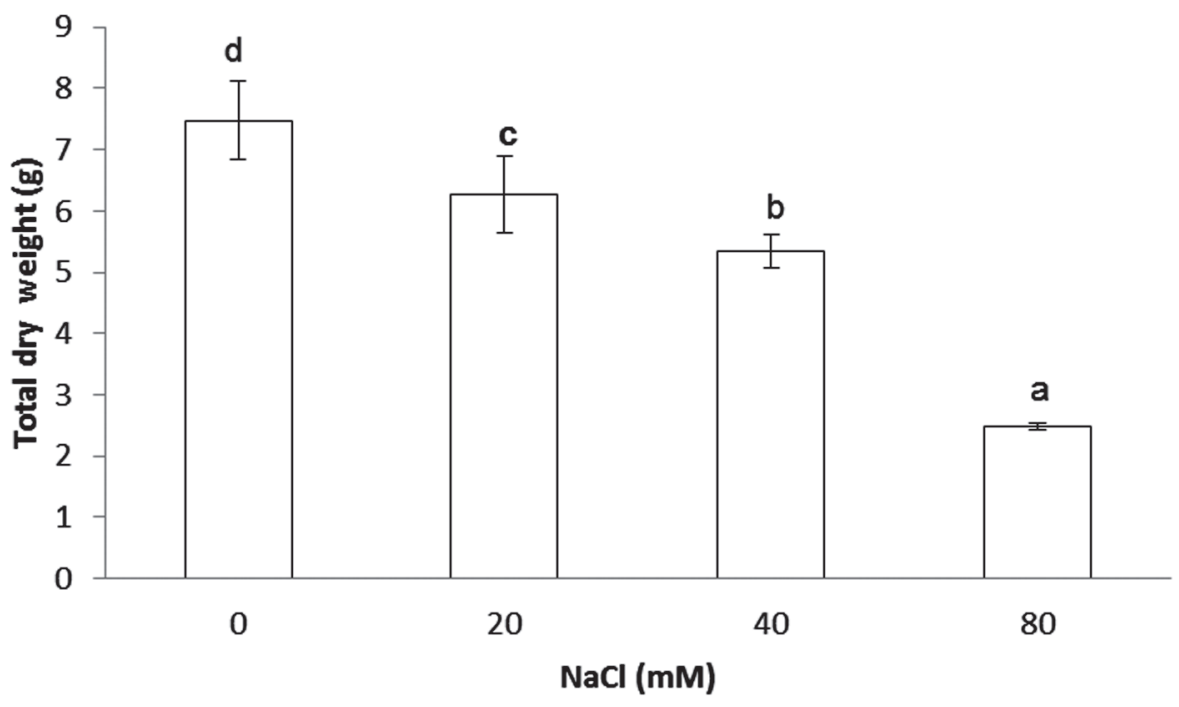

Figure 1. Dry weight banana passionfruit seedlings (Passiflora tripartita var. mollissima (Kunth) L. H. Bailey) exposed to saline stress. Same letter on columns do not differ significantly according to Turkey's HSD test ( $p>0.05)$. 
physiological and biochemical functions of the cell (Greenway \& Munns, 1980), reducing turgor, limiting photosynthesis (Schwarz \& Gale, 1981; Walker et al. 1981) and increasing ion deficiency due to inadequate transport mechanisms (Hasegawa et al. 1986).

As stated by Munns (2002), suppression of plant growth under saline conditions may either be due to the decreasing availability of water or to the increasing toxicity of sodium chloride associated with increasing toxicity of sodium chloride, connected with increasing salinity. Another possible reason for DM reduction could be the greater decline in uptake and use of mineral nutrients by plants under saline stress (Dadkhah E Grrifiths, 2006). Pessarakli \& Tucker (1985, 1988) reported that the total nitrogen uptake of cotton plants decreased with increasing salinity; the main shoot was not reduced as much as that of the root. Moreover, according to Cheeseman (1988), salinity stress imposes additional energy requirements on plant cells and diverts metabolic carbon to storage pools so that less carbon is available for growth.

The data obtained on leaf area showed differences between different variables of osmotic stress. Salinity concentration caused considerable reduction of leaf area. The reduction was higher $(\mathrm{p}<0.05)$ with80 $\mathrm{mM} \mathrm{NaCl}$, compared to the control (Figure 2).

Plants exposed to saline environment generally present a reduced leaf area, as also found in this study. Leaf area reduction can be attributed to the reduction of leaf growth in its central and distal part with increasing salinity (Bernstein et al. 1993). Leaf growth inhibition by salinity must be expected to occur via an effect on this region (Lazof $\mathcal{E}$ Bernstein, 1998).

Exposure of plants to high $\mathrm{NaCl}$ contents changed patterns of DM allocation in different organs of plant. Both the dry matter accumulated in leaves and petioles + stems + shoots showed statistically significant difference $(p<0.01)$. The addition of $80 \mathrm{mM} \mathrm{NaCl}$ reduced allocation of biomass to leaves in 36.6\% less than in the control (Figure 3). Between 20; $40 \mathrm{mM}$ and the control no significant difference was observed. In relation to DM accumulation in petioles + stems + shoots, the results were similar to those obtained for the leaves, with no significant difference between them; however, differing significantly $(p<0.05)$ from the treatment of $80 \mathrm{mM} \mathrm{NaCl}$; the plants presented $12.7 \%$ more dry matter than the control. Accumulated DM in the roots of treated plants showed in all cases no statistically significant different results.

In spite of the variation of DM in different parts of the plant with different salinity levels, the main effect of salinity on DM partitioning was the reduction of DM in leaves and the increase of DM accumulation in petioles + stems + shoots and roots (Figure 3). This suggests that the salinity affected the total DM distribution in different plant parts, as consequence of an adaptation mechanism of banana passionfruit plants to salinity, similar to other plant species exposed to salinity (Casierra-Posada E García, 2005; Casierra-Posada et al.

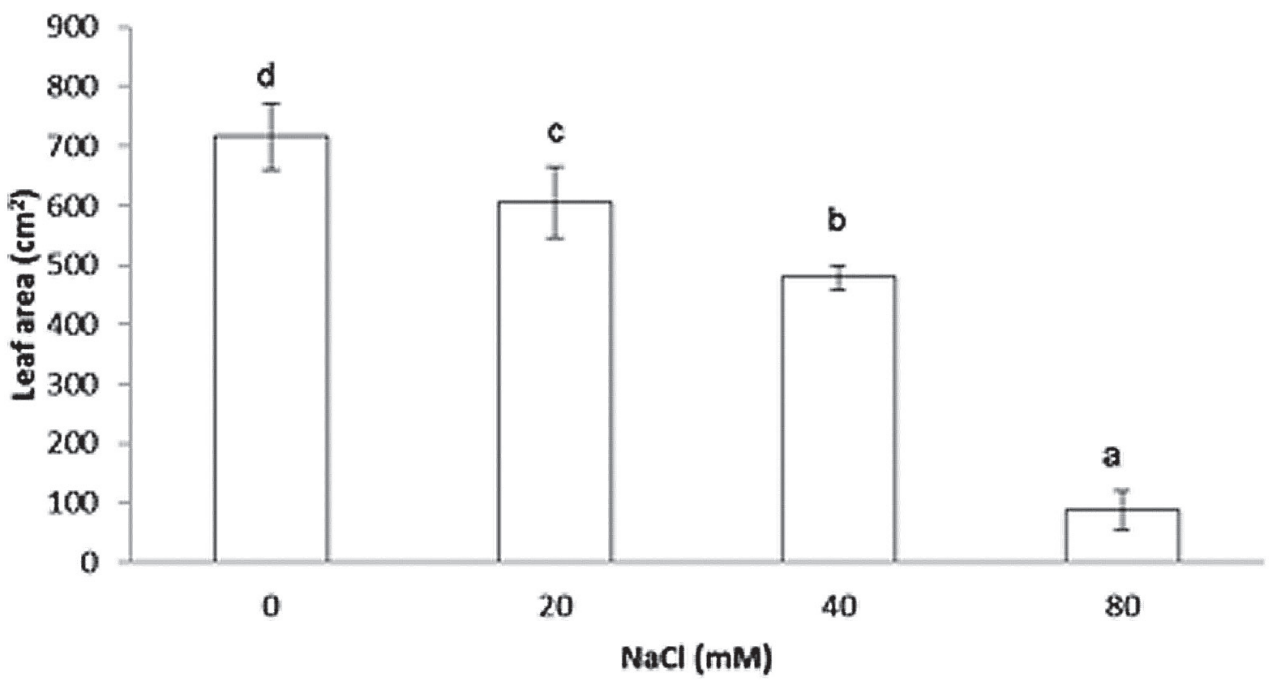

Figure 2. Leaf area of banana passionfruit seedlings (Passiflora tripartita var. mollissima (Kunth) L. H. Bailey) exposed to saline stress. Same letter on columns do not differ significantly according to Turkey's HSD test ( $p>0.05)$. 


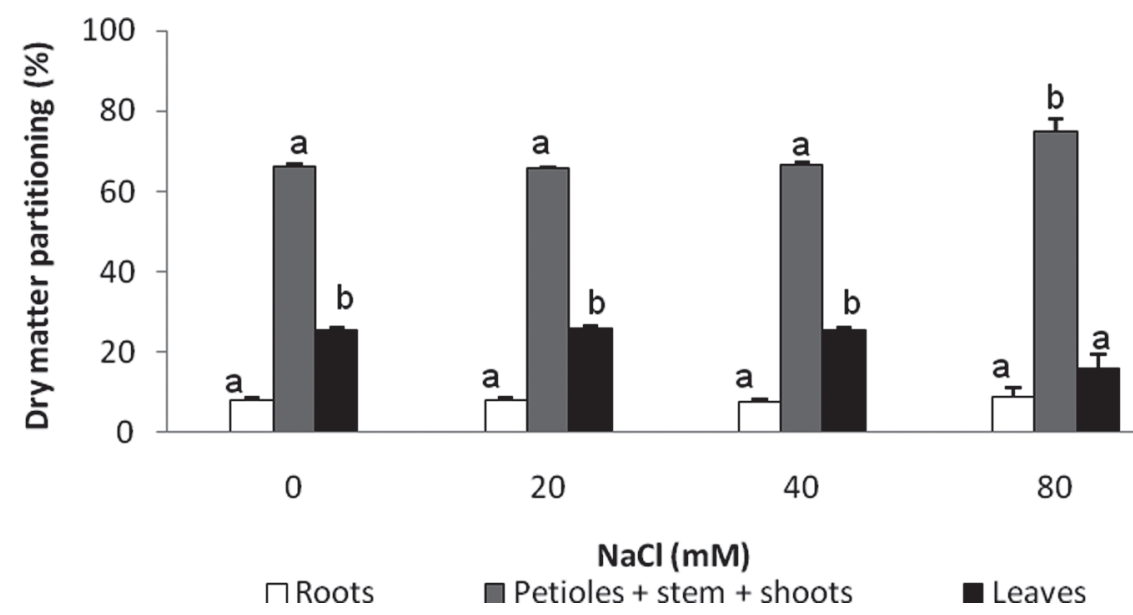

Figure 3. Dry matter partitioning on plant organs of banana passionfruit seedlings (Passiflora tripartita var. mollissima (Kunth) L. H. Bailey) exposed to saline stress. Same letter on columns of the same color do not differ significantly according to Turkey's HSD test $(p>0.05)$.

2006). Partitioning of photosynthetic materials among different organs is an important component of any crop growth description. However, up to date only limited attention has been given to this aspect and many crop models include only simple definitions where fixed fractions are partitioned to different organs throughout specific developmental phases (Weir et al. 1984). Milford et al. (1988) detected no evidence of a discontinuity in the partitioning between shoot and root in sugar beet, at any stage of development under normal conditions; they concluded that usually a progressive shift in partitioning to the storage root occurs as the crop develops. However, to understand the results reported by Milford et al. (1988) in relation to those found in this study, the anatomical differences between passion fruit plants and sugar beet should be taken into account.

The results of the present research suggest that salinity does not only reduce growth of banana passionfruit seedlings, but also alters the DM partitioning in the different plant organs, as an adaptive mechanism to salinity. Further studies are needed to determine the parameters related to chlorophyll fluorescence and gaseous exchange of individual leaves to bring complementary information on the nature of constraints acting on photosynthetic processes. This study suggests that the banana passionfruit is moderately sensitive to saline stress.

Acknowledgments: The team gratefully acknowledges the generous support of the Research Directorate (Dirección de Investigaciones - DIN) of the Pedagogical and Technological University of Colombia (UPTC), Tunja, for providing the funds and opportunity to conduct this research project. We also gratefully acknowledge matching support from the members of the Research Group in Plant Ecophysiology (Grupo Ecofisiología Vegetal) of the Faculty of Agricultural Sciences of the UPTC. Conflicts of interest: this document was prepared and reviewed with the participation of all authors, who report no conflict of interest that may be inherent in their submissions.

\section{BIBLIOGRAPHY}

1. ACKERLY, D.D.; BAZZAZ, F.A. 1995. Leaf dynamics, self-shading, and carbon gain in seedlings of a tropical pioneer tree. Oecologia. 101:289-298.

2. AGRONET. 2010. Análisis-Estadísticas. Ministerio de Agriculturay Desarrollo Rural. Available online in: http:// www.agronet.gov.co/agronetweb/AnalisisEstadisticas/ tabid/73/Default.aspx. (accessed 30/11/10).

3. BALL, M.C.; PIDSLEY, S.M. 1995. Growth responses to salinity in relation to distribution of two mangrove species, Sonneratia alba and S. lanceolata, in northern Australia. Funct. Ecol. 9:77-85.

4. BERNSTEIN, N.; LAÜCHLI, A.; SILK, W.K. 1993. Kinematics and dynamics of sorghum (Sorghum bicolor L.) leaf development at various $\mathrm{Na} / \mathrm{Ca}$ salinities: I. Elongation growth. Plant Physiology. 103:1107-1114.

5. BOHNERT, H.J.; SHEN, B. 1999. Transformation and compatible solutes. Sci. Hortic. 78:237-260. 
6. BRAY, E.A.; BAILEY-SERRES, J.; WERETILNYK, E. 2000. Responses to abiotic stresses. In: Buchanan B.B.; Gruissem W.; Jones R.L. (eds), Biochemistry and Molecular Biology of Plants, ASPP, Rockville. p.1158-1203.

7. CASPER, B.B.; FORSETH, I.N.; KEMPENICH, H.; SELTZER, S.; XAVIER, K. 2001. Drought prolongs leaf life span in the herbaceous desert perennial Cryptantha flava. Funct. Ecol. 15:740-747.

8. CASIERRA-POSADA, F.; EBERT, G.; LÜDDERS, P. 2000. Efecto de la salinidad por cloruro de sodio sobre el balance de nutrientes en plantas de Lulo. (Solanum quitoense L.). Agronomía Colombiana. 17:85-90.

9. CASIERRA-POSADA, F.; GARCÍA, N. 2005. Crecimiento y distribución de materia seca en cultivares de fresa (Fragaria sp.) bajo estrés salino. Agronomía Colombiana. 23(1):83-89.

10. CASIERRA-POSADA, F.; GARCÍA, N. 2006. Producción y calidad de fruta en cultivares de fresa (Fragaria sp.) afectados por estrés salino. Rev. Fac. Nal. Agr. Medellín. 59(2):3527-3542.

11. CASIERRA-POSADA, F.; PÉREZ, W.A.; PORTILLA, F. 2006. Relaciones hídricas y distribución de materia seca en especies de fique (Furcraea sp. Vent.) cultivadas bajo estrés por $\mathrm{NaCl}$. Agronomía Colombiana. 24(2):280-289.

12. CASIERRA-POSADA, F.; PACHÓN, C.A.; NIÑO-MEDINA, R.C. 2009. Changes in the quality characteristics of tomato (Solanum lycopersicum L.) fruits affected by $\mathrm{NaCl}$ salinity. Acta Hort. 82(1):235-240.

13. CHEESEMAN, J.M. 1988. Mechanisms of salinity tolerance in plants. J. Plant Physiol. 87:547-550.

14. CLOUGH, B.F. 1984. Growth and salt balance of the mangroves Avicennia marina (Forsk.) Vierh. and Rhizophora stylosa Griff. in relation to salinity. Aust. J. Plant Physiol. 11:419-430.

15. DADKHAH, A.R.; GRRIFITHS, H. 2006. The effect of salinity on growth, inorganic ions and dry matter partitioning in sugar beet cultivars. J. Agric. Sci. Technol. 8:199-210.

16. FISCHER, G.; CASIERRA-POSADA, F.; PIEDRAHITA, W. 2009. Ecofisiología de las especies pasifloráceas cultivadas en Colombia. pp. 45-67. En: Miranda, D.;
Fischer, G.; Carranza, C.; Magnitskiy, S.; Casierra, F., Piedrahita, W.; Flórez, L.E. (eds.). Cultivo, poscosecha y comercialización de las pasifloráceas en Colombia: maracuyá, granadilla, gulupa y curuba. Sociedad Colombiana de Ciencias Hortícolas, Bogotá. 357p.

17. GILBERT, G.A.; GADUSH, M.V.; WILSON, C.; MADORE, M.A. 1998. Amino acid accumulation in sink and source tissues of Coleus blumei Benth. during salinity stress. J. Exp. Bot. 49:107-114.

18. GREENWAY, H.; MUNNS, R. 1980. Mechanisms of salt tolerance in no halophytes. Annu. Rev. Plant Physiol. 31:149-190.

19. GUASMI, F.; FERCHICHI, A.; TOUIL, L; FẺRES, K.; MARZOUGUI, N. 2007. Analysis of genetic diversity to salt stress of South Tunisian barley cultivars using agronomic parameters. J. Biological Sci. 7(3):475-485.

20. HAMEED, M.; ASHRAF, M.; AHMAD, M.S.A.; NAZ, N. 2010. Structural and functional adaptations in plants for salinity tolerance. In: Ashraf, M.; Ozturk, M., Ahmad, M.S.A. (eds), Plant adaptation and phytoremediation. Springer Verlag. Berlin - Germany. p.151-170.

21. HASEGAWA, P.M.; BRESSAN, R.A.; HANDA, A.V. 1986. Cellular mechanism of salinity tolerance. Hort. Sci. 21(6):1317-1324.

22. HASEGAWA, P.M.; BRESSAN, R.A.; ZHU, J.K.; BOHNERT, H.J. 2000. Plant cellular and molecular responses to high salinity. Annu. Rev. Plant Physiol. Plant Mol. Biol. 51:463-499.

23. HU, Y.; SCHMIDHALTER, U. 2005. Drought and salinity: A comparison of their effects on mineral nutrition of plants. J. Plant Nutr. Soil Sci. 168:541-549.

24. LAZOF, D.; BERNSTEIN, N. 1998. The NaCl-induced inhibition of shoot growth: the case for disturbed nutrition with special consideration of calcium nutrition. Advances Bot. Res. 29:113-189.

25. LONGSTRETH, D.J.; STRAIN, B.R. 1977. Effects of salinity and illumination on photosynthesis and water balance of Spartina alterniflora Loisel. Oecologia. 31:191-199.

26. MEZA, N.; ARIZALETA, M.; BAUTTISTA, D. 2007. Efecto de la salinidad en la germinación y emergencia de semillas de parchita (Passiflora edulis f. flavicarpa). Rev. Fac. Agron. (LUZ). 24:69-80. 
27. MILFORD, G.F.J.; TRAVIS, K.Z.; POCOCK, T.O.; JAGGARD, K.W.; DAY, W. 1988. Growth and dry matter partitioning in sugar beet. J. Agr. Sci., 110:301-308.

28. MUNNS, R. 2002. Comparative physiology of salt and water stress. Plant Cell Environ. 28:239-250.

29. MUNNS, R.; TERMAAT, A. 1986. Whole-plant responses to salinity. Aust. J. Plant Physiol. 13:143-160.

30. NYAGAH, A.W.; MUSYIMI, D.M. 2009. Effects of sodium chloride solution stress on germination and growth of passion fruits seedlings. ARPN J. Agric. Biol. Sci. 4:49-53.

31. OZTURK, A.; UNLUKARA, A.; IPEK, A.; GURBUZ, B. 2004. Effects of salt stress and water deficit on plant growth and essential oil content of lemon balm (Melissa officinalis L.). Pak. J. Bot. 36(4):787-792.

32. PESSARAKLI, M.; TUCKER, T.C. 1985. Uptake of nitrogen- 15 by cotton under salt stress. Soil Sci. Soc. Am. J. 49:149-152.

33. PESSARAKLI, M.; TUCKER, T.C. 1988. Dry matter yield and nitrogen-15 uptake by tomatoes under sodium chloride stress. Soil Sci. Soc. Am. J. 52:698-700.

34. POLJAKOFF-MAYBER, A. 1975. Morphological and anatomical changes in plants as a response to salinity. In: Poljakoff-Mayber A.; Gale, J.; (eds.) Plants in saline environments. Berlin: Springer-Verlag. p.97-117.

35. SARI, A.O.; CEYLAN, A. 2002. Yield characteristics and essential oil composition of lemon balm (Melissa officinalis L.) grown in the Aegean Region in Turkey. Tr. J. of Agric. E Forestry. 26(4):217-224.
36. SCHWARZ, M.; GALE, J.; 1981. Maintenance respiration and carbon balance of plant at low levels of sodium chloride salinity. J. Exp. Bot. 32:933-941.

37. SERRAJ, R.; SINCLAIR, T.R. 2002. Osmolyte accumulation: can it really help increase crop yield under drought conditions? Plant Cell Environ. 25:333341.

38. SOARES, F.A.L.; GHEYI, H.R.; VIANA, S.B.A.; UYEDA, C.A.; FERNANDES, P.D. 2002. Water salinity and initial development of yellow passion fruit. Scientia Agricola. 59(3):491-497.

39. TANTAWY-ALAA, S.; ABDEL-MAWGOUD, A.M.R.; ELNEMR, M.A.; CHAMOUN, Y.G. 2009. Alleviation of salinity effects on tomato plants by application of amino acids and growth regulators. Eur. J. Sci. Res. 30:484-494.

40. WALKER, R.R.; TOROKFALVY, E.; STEELE, S.N.; KRIEDEMANN, N.E. 1981. An analysis of photosynthetic response to salt treatment in Vitis vinifera. Austr. J. Plant Physiol. 8:359-374.

41. WEIR, A.H.; BRAGY, P.L., PORTER, J.R.; RAYNER, J.H. 1984. A Winter wheat crop simulation model without water or nutrient limitations. J. Agr. Sci. 102:371-382.

42. WIGNARAJAH, K., JENNINGS, D.H.; HANDLEY, J.F. 1975. The effect of salinity on growth of Phaseolus vulgaris. I. Anatomical changes in the first trifoliolate leaf. Annals of Botany. 39:1029-1038.

Received: January 2, 2011

Accepted: April 30, 2011 